ISSN 0258-7122

Bangladesh J. Agril. Res. 37(3): 457-464, September 2012

\title{
AGRO-ECONOMIC ANALYSIS OF TUBEROSE CULTIVATION IN SELECTED AREAS OF BANGLADESH
}

\author{
M.A. HAQUE ${ }^{1}$, M. A. MONAYEM MIAH ${ }^{2}$ \\ S. HOSSAIN ${ }^{3}$ AND S. M. SHARIFUZZAMAN ${ }^{4}$
}

\begin{abstract}
The study identified agronomic practices, analyzed relative profitability, and resource use efficiency of tuberose cultivation in Bangladesh during January 2010. Primary data were collected from 100 randomly selected farmers from Jessore and Chuadanga districts. The results revealed that the per hectare costs of tuberose cultivation were estimated at Tk. 2,00,761 and Tk. 1,29,283 over full cost and variable cost, respectively. The major share of total cost was for human labour (30\%) followed by land use (23\%), and fertilizer (17\%). The total cost was $26 \%$ and $12 \%$ higher than its competitive crops banana and papaya, respectively. The yield of tuberose was 4,54,425 sticks per hectare. The gross margin and net return were Tk. 5,52,354 and Tk.4,80,876 per hectare, respectively. This net return was $65 \%$ higher than banana and $71 \%$ higher than papaya cultivation. The BCRs (benefit cost ratio) were 5.27 and 3.39 over variable cost and full cost basis, respectively. Production function revealed that human labour, seedling and irrigation had positive effect on tuberose cultivation. The lack of scientific knowledge, high yielding variety and efficient transport facility were reported to be major problems in tuberose cultivation.
\end{abstract}

Keywords: Tuberose, relative profitability, gross margin, net return and BCR.

\section{Introduction}

Commercial floriculture in Bangladesh is a new dimension in farming culture. Evidences from all civilizations reveal that mankind has historical interest in gardening and culturing flowers to satisfy their aesthetic needs. But, in the present world, flower becomes important not only for its aesthetic social values, but also for its economic contribution (Aditya, 1992; Dadlani, 2003). People usually use flowers in all their ceremonies like wedding, birthday and marriage day greetings, religious offerings and sometimes in social, political and historical occasions. The universal usage has created a real trend of producing flower on a commercial basis to meet increasing demand in the market. The statistics shows that the area and production of flowers in Bangladesh during 2008-09 were 520.64 ha and 4308 MT, respectively (BBS, 2008).

${ }^{1}$ Principal Scientific Officer, ${ }^{2}$ Senior Scientific Officer, ${ }^{3}$ Chief Scientific Officer, Agricultural Economics Division, Bangladesh Agricultural Research Institute (BARI) and ${ }^{4}$ Senior Scientific Officer, HRC, BARI, Gazipur-1701, Bangladesh. 
Considering the demand and market price of flowers, some enthusiastic farmers have started cultivation of various flowers like gladiolus, tuberose, marigold, rose, gerbera, and orchid on commercial basis. The tuberose farmers are lacking of improved technology and depriving from fair prices of their produces for various reasons that need to be explored. Besides, the flower scientists, research managers, and policy makers in the country are also lacking of socio-economic data and information regarding tuberose cultivation which are very much important for further development of the crop.

Therefore, the present study was undertaken to fulfill the following objectives:

(i) to identify the existing agronomic practices of tuberose cultivation at farm level;

(ii) to measure the relative profitability of tuberose with major competing crops;

(iii) to find out the factors affecting the yield of tuberose cultivation;

(iv) to explore the socio-economic constraints to its higher production.

\section{Materials and Method}

Sampling technique: The present study was conducted in Jhikorgacha Upazila of Jessore district and Sadar Upazila of Chuadanga district during the month of January 2010. A complete list of tuberose growers were collected by the help of DAE personnel from the study areas and finally a total of 100 tuberose farmers taking 50 farmers from each area were randomly selected for the study. Again, banana and papaya cultivation were taken into consideration as competing crops to compare the cost and benefit of tuberose cultivation. The competitive crops were selected on the basis of soil and land type where tuberose is generally cultivated in the study areas. A total of 100 farmers were selected from each location for each competitive crop.

Method of data collection: The researcher along with experienced enumerators collected primary data and information from tuberose farmers with the help of a pre-tested interview schedule. The data were collected through face to face interview method. Second year tuberose gardens were selected for primary data collection because commercial harvesting starts in the second year.

Analytical technique: Both tabular and functional methods of analyses were employed in this study. At first, the collected data were edited and summarized for analysis. The tabular method of analysis involved different descriptive statistics like mean, percentage, ratio, etc. Land use cost was calculated on the basis of per year lease value of land. The profitability of tuberose cultivation was estimated using gross margin, net return, and benefit cost analysis. 
Cobb-Douglas production function was used to find out the factors affecting the yield of tuberose production. The functional form of the Cobb-Douglas model is given below:

$$
\mathrm{Y}=\mathrm{AX}_{1}{ }^{\mathrm{b} 1} \mathrm{X}_{2}{ }^{\mathrm{b} 2}
$$

The production function was converted to logarithmic form so that it could be solved by least square method i.e.

$$
\ln Y=\operatorname{lna}+b_{1} \ln X_{1}+\ldots \ldots \ldots \ldots \ldots \ldots \ldots b_{n} \ln X_{n}+U_{i}
$$

The empirical production function was the following:

$$
\begin{aligned}
\ln Y= & a+b_{1} \ln X_{1}+b_{2} \ln X_{2}+b_{3} \ln X_{3}+b_{4} \ln X_{4}+b_{5} \ln X_{5}+b_{6} \ln X_{6}+ \\
& b_{7} \ln X_{7}+b_{8} \ln X_{8}+b_{9} \ln X_{9}+U_{i}
\end{aligned}
$$

Where,

$\mathrm{Y}=$ Yield (Stick/ha); $\mathrm{X}_{1}=$ Human Labour (Man-day/ha); $\mathrm{X}_{2}=$ Land preparation cost (Tk/ha); $X_{3}=$ Seedling (Tk/ha); $X_{4}=$ Manure (kg/ha); $X_{5}=$ Urea (kg/ha); $X_{6}$ $=\operatorname{TSP}(\mathrm{kg} / \mathrm{ha}) ; X_{7}=\operatorname{MoP}(\mathrm{kg} / \mathrm{ha}) ; X_{8}=$ Insecticide cost $(\mathrm{Tk} / \mathrm{ha}) ; \mathrm{X}_{9}=$ Irrigation cost (Tk/ha); $a=$ Intercept; $b_{1}, b_{2}-----b_{9}$ coefficients of the respective variables to be estimated. $\mathrm{U}_{\mathrm{i}}=$ Error term.

\section{Results and Discussion}

\section{Agronomic practices adopted}

It was found that all the respondent farmers used power tiller for land preparation. The average number of ploughings per farm was five. The number of ploughings was higher in Jessore than in Chuadanga. All the farmers planted tuberose seedling in line. The planting time of tuberose started from March and continued up to April. The average number of weedings, insecticide spraying and irrigation per farm were 10,4 , and 11 , respectively. The plucking time of tuberose varied from September to May. On an average, 88\% respondent farmers in the study areas cultivated double type tuberose, but only $12 \%$ farmers cultivated single type tuberose (Table 1).

\section{Input use pattern}

The number of human labour used for producing tuberose was 571 man-days per hectare. The use of human labour was found to be higher in Jessore than in Chuadanga due to proper management of land. The costs of land preparation and seedling were Tk. 6,408 and Tk. 14,910 per hectare. They used 6.53 tons of manure per hectare. They also used chemical fertilizers like urea, TSP, MoP, zipsum, and zinc sulphate at the rate of $274 \mathrm{~kg}, 268 \mathrm{~kg}, 216 \mathrm{~kg}, 54 \mathrm{~kg}$, and $7 \mathrm{~kg}$ per hectare (Table 2). 
Table 1. Agronomic practices of tuberose production in different study areas.

\begin{tabular}{lcccc}
\multicolumn{1}{c}{ Items } & Jessore & Chuadanga & All areas \\
\hline Ploughing (no./farm) & 6 & 4 & 5 \\
Planting method (\% of farmers): & & & \\
Line & 100 & 100 & 100 \\
Planting time & March- April & March- April & March- April \\
Weeding (no./farm) & 8 & 10 & 10 \\
Spraying insecticides (no./farm) & 5 & 4 & 5 \\
Irrigation (no./farm) & 12 & 10 & 11 \\
Harvesting time & Sep.-May & Sep.- May & Sep.-May \\
Types of tuberose (\% of farmers): & & & 12 \\
$\quad$ Single & 15 & 10 & 88 \\
$\quad$ Double & 85 & 90 & 100 \\
\hline Total & 100 & 100 & \\
\hline
\end{tabular}

Table 2. Input use pattern of tuberose production in different study areas.

\begin{tabular}{lcc|c}
\hline \multicolumn{1}{c}{ Items } & Jessore & Chuadanga & All areas \\
\hline Human labour (man-day/ha): & & & \\
$\quad$ Family & 281 & 218 & 250 \\
$\quad$ Hired & 300 & 342 & 321 \\
$\quad$ Total & 581 & 560 & 571 \\
Land preparation cost (Tk./ha): & 7285 & 5532 & 6408 \\
Seedling (Tk./ha) & 16613 & 13207 & 14910 \\
Manures (kg/ha) & 8850 & 4201 & 6525 \\
Fertilizers (kg/ha) & & & \\
$\quad$ Urea & 291 & 256 & 274 \\
TSP & 265 & 271 & 268 \\
MoP & 187 & 246 & 216 \\
Zipsum & 108 & - & 54 \\
Zinc sulphate & 5 & 9 & 7 \\
Insecticides (Tk./ha) & 871 & 522 & 697 \\
Irrigation (Tk./ha) & 26271 & 23580 & 24925 \\
\hline
\end{tabular}




\section{Cost and return of tuberose cultivation}

All variable costs incurred for human labour, land preparation, seedling, organic manure, fertilizers, insecticides, irrigation were considered for calculating the cost of tuberose cultivation. The cost of land use was calculated on the basis of prevailing local lease value of land. The average costs of tuberose cultivation were Tk.200761 and Tk.129283 per hectare on total cost and variable cost basis respectively. The major share of total cost was for human labour (30\%), land use (23\%), fertilizer (17\%), and irrigation (12\%). The cost of cultivation of tuberose in Jessore was higher compared to Chuadanga due to higher cost of seedling, organic manures, irrigation and insecticides (Table 3).

Table 3. Cost of production of tuberose in different study areas.

\begin{tabular}{l|c|c|c}
\multicolumn{1}{c}{ Items } & Jessore & Chuadanga & All areas \\
\hline A. Variable costs & $131150(62)$ & $127417(68)$ & $129283(64)$ \\
Land preparation & $7285(4)$ & $5532(3)$ & $6408(3)$ \\
Hired labour & $30266(14)$ & $38229(20)$ & $34247(17)$ \\
Seedling & $16613(8)$ & $13208(7)$ & $14910(8)$ \\
Organic manure & $7845(4)$ & $1575(1)$ & $4710(2)$ \\
Chemical fertilizers: & $32865(15)$ & $35449(19)$ & $34157(17)$ \\
$\quad$ Urea & 3647 & 3069 & 3358 \\
$\quad$ TSP & 20101 & 21047 & 20574 \\
$\quad$ MoP & 7827 & 9848 & 8837 \\
Zipsum & 522 & - & 261 \\
Zink & 768 & 1485 & 1127 \\
Insecticides & $871(1)$ & $522(-)$ & $697(-)$ \\
Irrigation & $26271(12)$ & $23580(12)$ & $24926(12)$ \\
Interest on operating & $9134(5)$ & $9322(5)$ & $9228(5)$ \\
capital & & & \\
B. Fixed cost & $82911(39)$ & $60045(32)$ & $71478(36)$ \\
Family labour & $28272(13)$ & $24439(13)$ & $26356(13)$ \\
Land use & $54639(26)$ & $35606(19)$ & $45122(23)$ \\
Total cost (A+B) & $214061(100)$ & $187462(100)$ & $200761(100)$ \\
\hline
\end{tabular}

Figures within the parentheses indicate percentage of total cost 
The average number of tuberose plucked per hectare was 4,54,425 sticks. The yield (sticks/ha) of tuberose was reportedly higher in Jessore compared to that in Chuadanga due to better land preparation and fertile soil (Table 4). The cost of production of tuberose was $26 \%$ and $12 \%$ higher than its competitive crops banana and papaya, respectively (Table 5). The gross return and gross margin of tuberose cultivation was estimated at Tk. 6,81,637 and Tk. 5,52,354 per hectare respectively. Gross margin was found to be higher in Jessore than in Chuadanga. The net return of tuberose cultivation was Tk 4,80,876 per hectare. It was found higher in Chuadanga than Jessore due to lower cost of production. The net returns from tuberose cultivation were $65 \%$ and $71 \%$ higher than banana and papaya, respectively (Table 5). The benefit cost ratios were 5.27 and 3.39 over total cost and variable cost, respectively.

Table 4. Profitability of tuberose cultivation in the study areas,

\begin{tabular}{lcccc}
\hline \multicolumn{1}{c|}{ Items } & Jessore & Chuadanga & All areas \\
\hline Total variable cost (Tk,/ha) & 131150 & 127417 & 129283 \\
Total cost (Tk,/ha) & 214061 & 187462 & 200761 \\
Yield (Sticks/ha) & 457283 & 451567 & 454425 \\
Price (Tk,/stick) & 1.5 & 1.5 & 1.5 \\
Gross return (Tk,/ha) & 685925 & 677350 & 681637 \\
Gross margin (Tk,/ha): & 554775 & 549933 & 552354 \\
Net return (Tk,/ha) & 471864 & 489888 & 480876 \\
Benefit cost ratio: & & & \\
$\quad$ Over variable cost & 5.23 & 5.32 & 5.27 \\
\multicolumn{1}{c}{ Over total cost } & 3.20 & 3.61 & 3.39 \\
\hline
\end{tabular}

Table 5. Relative economic performance of tuberose with other competitive crops,

\begin{tabular}{l|c|c|c|c|c}
\hline \multicolumn{1}{c|}{ Items } & Tube rose & Banana & $\begin{array}{c}\text { \% higher } \\
\text { than } \\
\text { banana }\end{array}$ & Papaya & $\begin{array}{c}\text { (Figure in Tk/ha) } \\
\text { \% higher/lower } \\
\text { than papaya }\end{array}$ \\
\hline A. Gross return & 681637 & 314250 & 54 & 314440 & 54 \\
$\begin{array}{l}\text { B. Total variable } \\
\text { cost }\end{array}$ & 129283 & 103019 & 20 & 182318 & -41 \\
C. Total cost & 200761 & 148141 & 26 & 177244 & 12 \\
Gross margin (A-B) & 552354 & 211231 & 62 & 182318 & 67 \\
Net return (A-C) & 480876 & 166109 & 65 & 137196 & 71 \\
Benefit cost ratio & 3.39 & 2.12 & 37 & 1.77 & 48 \\
\hline
\end{tabular}




\section{Factors affecting tuberose yield}

Cobb-Douglas production function was used to determine the contribution of inputs like human labour, land preparation, seedling, manure, urea, TSP, MoP, insecticide, and irrigation for tuberose production (Table 6). Functional analysis revealed that the co-efficient of human labour, seedling, and irrigation are positively significant at $1 \%$ level indicate that $1 \%$ increase in the use of these inputs, keeping other factors remaining constant, would increase the yield of tuberose by $0.01 \%, 0.007 \%$, and $0.002 \%$, respectively. The co-efficient of manures, urea, TSP, and MoP were negative and significant at $5 \%, 1 \%, 1 \%$, and $1 \%$ level, respectively. It indicated that the production of tuberose decreased with lower use of manures and higher use of urea, TSP, and MoP than the recommended doses.

Table 6. Estimated coefficients and their related statistics of production function for tuberose,

\begin{tabular}{lcc}
\hline \multicolumn{1}{c|}{ Explanatory Variables } & Co-efficient & t-values \\
\hline Intercept & 0.85 & 212.53 \\
Human labour $\left(\mathrm{X}_{1}\right)$ & $0.01^{* * *}$ & 3.06 \\
Land preparation $\left(\mathrm{X}_{2}\right)$ & $0.007 \mathrm{~ns}$ & 0.65 \\
Seedling $\left(\mathrm{X}_{3}\right)$ & $0.01^{* * *}$ & 3.50 \\
Manure $\left(\mathrm{X}_{4}\right)$ & $-0.005^{* *}$ & -4.25 \\
Urea $\left(\mathrm{X}_{5}\right)$ & $-0.003^{* * *}$ & -3.20 \\
$\mathrm{TSP}\left(\mathrm{X}_{6}\right)$ & $-0.02^{* * *}$ & -4.50 \\
MoP $\left(\mathrm{X}_{7}\right)$ & $-0.004^{* * *}$ & -2.20 \\
Insecticides $\left(\mathrm{X}_{8}\right)$ & $-0.001 \mathrm{~ns}$ & 0.85 \\
Irrigation $(\mathrm{X})$ & $0.002^{* * *}$ & 4.20 \\
$\mathrm{R}^{2}$ & 0.68 & - \\
$\mathrm{F}$ value & $35.62^{* * *}$ & - \\
\hline
\end{tabular}

Note: $* * *$ and $* *$ indicate significant at $1 \%$ and $5 \%$ level, respectively.

The value of coefficient of determination $\left(\mathrm{R}^{2}\right)$ was 0.68 , which indicated that around $68 \%$ of the variation in yield was explained by the independent variables included in the model. The F-value was found 35.62 which were significant at $1 \%$ level implying that the variation of yield mainly depends on the explanatory variables included in the model.

\section{Problems of tuberose cultivation}

The farmers in the study areas encountered different problems during tuberose cultivation. The problems were ranked based on their priority. First ranked problem was lack of technical knowledge about improved cultivation practices of tuberose followed by lack of HYV seedling, and lack of efficient transport facility (Table 7). 
Table 7. Constraints to tuberose cultivation in different study areas.

\begin{tabular}{l|c|c|c}
\hline \multirow{2}{*}{ Constraints } & \multicolumn{3}{c}{ Rank value } \\
\cline { 2 - 4 } & Jessore & Chuadanga & All areas \\
\hline $\begin{array}{l}\text { 1. Lack of technical knowledge about } \\
\text { improved cultivation practices }\end{array}$ & 1 & 1 & 1 \\
2. Non- availability of HYV seeds & 2 & 2 & 2 \\
3. Lack of efficient transport facilities & 3 & 3 & 3 \\
\hline
\end{tabular}

\section{Conclusion and Recommendations}

The economic performance of tuberose cultivation in selected areas of Bangladesh has been evaluated in this study. The results revealed that tuberose cultivation is highly profitable at farm level. Its cultivation is also profitable compared to its competitive crops banana and papaya. Human labour, seedling, and irrigation had positive effect on the yield of tuberose cultivation. The study also revealed that due to various socio-economic constraints, the tuberose farmers can not receive expected yield and price of their produces.

Based on the findings of the study, the following recommendations were put forward for the improvement of tuberose cultivation at farm level.

1) HYV tuberose seedlings should be made available to the farmers at proper time.

2) Training on tuberose cultivation may be organized by both government and non-government organizations to develop technical knowledge of the farmers.

3) Market infrastructure should be developed in terms of quick transportation, proper storage and other physical facilities to reduce spoilage and damage.

\section{References}

Aditya, D.K. 1992.Floriculture in national economy. Proceedings of the $6^{\text {th }}$ National Horticultural Conference and Symposium. BSHS, Pp. 30-35.

BBS, 2008. Yearbook of Agricultural Statistics of Bangladesh, Bangladesh Bureau of Statistics, Ministry of Planning, GOB, Dhaka.

Dadlani, N.K. 2003. Global Positioning of Bangladesh Floriculture. A Paper presented on a Seminar held on $6^{\text {th }}$ November, 2003, BARC, Farmgate, Dhaka. 